\title{
EFEKTIVITAS EKSTRAK DAUN JARAK PAGAR (Jatropha curcas L.) DALAM MENGHAMBAT SERANGAN NEMATODA PURU AKAR (Meloidogyne spp.) PADA TANAMAN TOMAT
}

\author{
Eky Santo $^{1}$, Djamilah ${ }^{2 *}$, Entang Inoriah ${ }^{1}$ \\ ${ }^{1}$ Program Studi Agroekoteknologi, Fakultas Pertanian Universitas Bengkulu \\ 2Program Studi Proteksi Tanaman, Fakultas Pertanian Universitas Bengkulu \\ *Corresponding Author :djamilah@unib.ac.id
}

\begin{abstract}
[THE EFFECTIVENESS Jatropha curcas (L.) LEAF EXTRACTS IN INHIBIT ROOT-KNOT NEMATODE (Meloidogyne spp.) INJURIES ON TOMATO]. One of the main problems in tomato cultivation is the attack of root purse nematodes (Meloidogyne spp.). Some methods of controlling Meloidogyne spp. which can be done including using plants as vegetable nematicides. This study aims to get the concentration of Jatropha leaf extract which is effective in inhibiting the Meloidogyne spp attack on tomato plants. This study used 48 plants, 24 plants for observation 35 days after planting and 24 plants for observation until the age of 77 days after planting. This study used a Completely Randomized Design (CRD) with the treatment of Jatropha leaf extract concentrations $(0 \%, 10 \%$, $20 \%, 30 \%, 40 \%, 50 \%$ ), and repeated four times. The results showed Jatropha curcas extract in inhibiting the attack of root purse nematodes (Meloidogyne spp.) can maintain plant height, fruit number, fruit weight, and plant stover wet weight 35 days after planting, but no significant effect on stover wet weight plants 77 days after planting and dry weight of plant stover 35 days after planting and 77 days after planting. The concentration of Jatropha leaf extract tends to increase the concentration, the smaller the rate of infection and the population of Meloidogyne spp on tomato plants. The concentration of Jatropha leaf extract 35\% - 45\% is the optimum concentration in inhibiting Meloidogyne spp. on tomato plants.
\end{abstract}

Keyword: jatropha, Meloidogyne spp., nematicides, tomato

\begin{abstract}
ABSTRAK
Salah satu permasalahan utama_dalam budidaya tomat adalah serangan nematoda puru akar (Meloidogyne spp.). Beberapa cara pengendalian Meloidogyne spp. yang dapat dilakukan_di antaranya_dengan memanfaatkan tanaman sebagai nematisida nabati. Penelitian ini bertujuan untuk mendapatkan konsentrasi ekstrak daun jarak pagar yang efektif dalam menghambat serangan Meloidogyne spp. pada tanaman tomat. Penelitian ini menggunakan 48 tanaman yaitu 24 tanaman untuk pengamatan 35 hari setelah tanam dan 24 tanaman untuk pengamatan sampai umur 77 hari setelah tanam. Penelitian ini menggunakan Rancangan Acak Lengkap (RAL) dengan perlakuan konsentrasi ekstrak daun jarak pagar $(0 \%, 10 \%, 20 \%, 30 \%, 40 \%, 50 \%)$, dan diulang sebanyak empat kali. Hasil penelitian menunjukkan ekstrak daun jarak pagar (Jatropha curcas) dalam menghambat serangan nematoda puru akar (Meloidogyne spp.) dapat mempertahankan tinggi tanaman, jumlah buah, bobot buah dan bobot basah brangkasan tanaman 35 hari setelah tanam, namun berpengaruh tidak nyata terhadap bobot basah brangkasan tanaman 77 hari setelah tanam dan bobot kering brangkasan tanaman 35 hari setelah tanam dan 77 hari setelah tanam. Konsentrasi ekstrak daun jarak pagar memiliki kecenderungan semakin besar pemberian konsentrasi, maka semakin kecil tingkat infeksi dan populasi Meloidogyne spp. pada tanaman tomat. Konsentrasi ekstrak daun jarak pagar $35 \%-45 \%$ merupakan konsentrasi yang optimum dalam menghambat serangan Meloidogyne spp. pada tanaman tomat.
\end{abstract}

Kata kunci: jatropha, Meloidogyne spp. nematisida, tomat 


\section{PENDAHULUAN}

Kebutuhan masyarakat terhadap tomat (Lycopersicum esculentum Mill) akan terus mengalami peningkatan seiring dengan pertambahan jumlah penduduk dan daya belinya. Agar kebutuhan tersebut terpenuhi, maka harus diimbangi dengan peningkatan jumlah produksinya. Provinsi Bengkulu merupakan daerah yang berpotensi sebagai penghasil buah tomat, akan tetapi dalam beberapa tahun terakhir mengalami penurunan yang cukup besar. Pada tahun 2012 produksi buah tomat 33.351 ton, kemudian pada tahun tahun 2013 menurun menjadi 26.583 ton dan semakin menurun pada tahun 2014 menjadi hanya 23.494 ton (BPS, 2015).

Berbagai faktor pembatas yang mempengaruhi produktivitas buah tomat, salah satunya karena adanya gangguan dari Organisme Pengganggu Tanaman (OPT). Jenis OPT penting yang sering menyerang pertanaman tomat adalah nematoda parasit tumbuhan Meloidogyne spp. yang bersifat polifagus dan populasinya telah menyebar di seluruh dunia sehingga termasuk dalam golongan hama yang berbahaya (Adiputra, 2006).

Tanaman yang terserang Meloidogyne spp. dapat mengakibatkan berkurangnya fungsi akar tanaman secara normal, karena nematoda parasitik tanaman umumnya_mengganggu proses pengangkutan unsur hara dari dalam tanah ke bagian jaringan tanaman di atas permukaan tanah (Dropkin, 1992). Meloidogyne spp. merupakan nematoda yang berkembang sangat cepat dan mempunyai daya tekan tinggi terhadap pertumbuhan tanaman dengan gejala khas terlihat pada akar berupa bintil-bintil yang disebut dengan puru akar (Whitehead, 1998). Selain terbentuknya gall atau puru pada sistem perakarannya, tanaman yang terserang Meloidogyne spp. juga menyebabkan daun tanaman mengalami klorosis, tanaman kerdil, daun layu dan gugur, akar lebih sedikit, dan bila tanaman terserang hebat atau parah maka tanaman akan mati (Taylor \& Sasser, 1978).

Sebagian besar petani menggunakan pestisida sintetik_untuk melindungi tanaman tomat dari gangguan Meloidogyne spp. Sebagai contoh petani di India selama satu musim tanaman tomat dilakukan penyemprotan pestisida sintetik lebih dari 50 kali (Nagaraju et al., 2002). Penyalahgunaan pestisida ini menyebabkan efek buruk terhadap lingkungan, kesehatan manusia dan juga menyebabkan naiknya ongkos produksi. Sekitar $31 \%$ dari total ongkos produksi tomat di Philipina harus dikeluarkan untuk biaya pembelian_pestisida (Orden et al., 1994).

Penggunaan pestisida dengan bahan aktif yang sangat toksik dan sulit terdegradasi juga menimbulkan berbagai dampak negatif, seperti hilangnya keragaman hayati, menurunnya populasi organisme berguna seperti musuh alami hama dan terjadinya pencemaran lingkungan (Isenring, 2010). Dampak negatif lainnya akibat penggunaan pestisida adalah meningkatnya resistensi dan resurjensi organisme pengganggu tanaman (Las et al., 2006). Sifat resisten ini akan mengakibatkan penurunan produksi yang signifikan bahkan dapat menyebabkan gagal panen, sehingga keberlanjutan usahatani dapat terancam.

Upaya pengendalian nematoda pada umumnya dilakukan secara kimiawi dengan menggunakan nematisida sintetik. Nematisida yang sering digunakan untuk mengendalikan Meloidogyne spp. biasanya berbahan aktif metil bromida yang berbentuk fumigan dan non-fumigan (Luc et al., 1995). Penggunaan nematisida dapat menimbulkan dampak negatif terhadap hasil pertanian, lingkungan, dan manusia terutama apabila penggunaan nematisida terlalu berlebihan. Oleh karena itu para pakar telah berusaha mencari alternatif dalam pengendalian Meloidogyne spp. selain secara kimia. Seiring perkembangan zaman dan kemajuan teknologi, penelitian pengendalian nematoda non-kimiawi terus dilakukan untuk mendapatkan bahan nematisida yang lebih aman bagi manusia dan lingkungan, dengan harga terjangkau tetapi memiliki efektivitas relatif tidak berbeda dengan pengendalian penggunaan nematisida sintetik. _Salah satu teknik yang dapat diterapkan adalah pemanfaatan nematisida nabati (Javed et al., 2006).

Beberapa jenis tanaman mengandung senyawa toksik terhadap nematoda yang sangat potensial untuk dikembangkan sebagai nematisida nabati, di antaranya adalah daun jarak pagar (Jatropha curcas L.) (Mustika, 2005).. Penelitian yang dilakukan oleh Sharma et al. (2012) menunjukkan bahwa daun jarak pagar mengandung zat-zat berupa alkaloid, saponin, tanin, terpenoid, steroid, glikosida, senyawa fenol, dan flavonoid. Nwokocha et al. (2011) merincikan bahwa daun jarak pagar memiliki kandungan tanin pada daun sebesar 7,43\%, alkaloids sebesar $4,54 \%$ dan flavonoloids sebesar 2,76\%, sementara itu konsentrasi saponin pada daun 4,89\% dan phenols $0,59 \%$ yang dapat digunakan sebagai nematisida. Tujuan penelitian ini adalah untuk mendapatkan konsentrasi ekstrak daun jarak pagar yang efektif dalam menghambat serangan nematoda puru akar (Meloidogyne spp.) pada tanaman tomat.

\section{METODE PENELITIAN}

Penelitian ini dilaksanakan pada bulan Desember 2015 sampai Februari 2016 di Kelurahan Kandang Limun, Kecamatan_Muara Bangkahulu, Kota Bengkulu dan di_Laboratorium Proteksi Tanaman, Fakultas Pertanian, Universitas Bengkulu. Penelitian ini menggunakan Rancangan Acak Lengkap (RAL) dengan enam perlakuan yang masing-masing diulang sebanyak empat kali. Perlakuan tersebut berturut-turut : (1) penyiraman tanpa ekstrak daun jarak pagar, (2) penyiraman dengan ekstrak daun jarak pagar konsentrasi $10 \%$ campuran $10 \mathrm{~mL}$ ekstrak daun jarak pagar 
dan $90 \mathrm{~mL}$ air, (3) penyiraman dengan ekstrak daun jarak pagar konsentrasi $20 \%$ campuran 20 $\mathrm{mL}$ ekstrak daun jarak pagar dan $80 \mathrm{~mL}$ air, (4) penyiraman dengan_ekstrak daun jarak pagar konsentrasi 30\% campuran $30 \mathrm{mlL}$ ekstrak daun jarak pagar dan $70 \mathrm{~mL}$ air, (5) penyiraman dengan ekstrak daun jarak pagar konsentrasi $40 \%$ campuran 40 $\mathrm{mL}$ ekstrak daun jarak pagar dan $60 \mathrm{~mL}$ air, dan (6) penyiraman dengan ekstrak daun jarak pagar konsentrasi $50 \%$ campuran $50 \mathrm{~mL}$ ekstrak daun jarak pagar dan $50 \mathrm{~mL}$ air.

Ekstrak daun jarak pagar dibuat dengan cara mengumpulkan daun tanaman jarak pagar yang sudah berwarna hijau tua, dikeringanginkan dan selanjutnya diblender hingga menjadi formulasi bubuk. Bubuk tersebut dimasukan dalam nampan dan dicampur dengan air dengan perbandingan $1: 3$, didiamkan selama 24 jam dan selanjutnya disaring dengan menggunakan kain saring sehingga diperoleh larutan nematisida (Tohir, 2010). Nematisida diaplikasikan pada hari ketiga setelah infestasi nematoda dengan cara disiramkan di sekitar perakaran tanaman sebanyak $100 \mathrm{~mL} /$ tanaman.

Sumber inokulum awal Meloidogyne spp. diambil dari akar tanaman tomat yang terserang, kemudian dibersihkan dan dipotong-potong sepanjang $0,5 \mathrm{~cm}$, kemudian diekstraksi dengan metode modifikasi corong Baermann selama 24 jam. Setelah inokulum didapat, selanjutnya dilakukan perbanyakan pada tanaman tomat yang berumur 2 minggu pada media campuran tanah steril dan pupuk kandang dengan perbandingan $2: 1$. Pemeliharaan inokulum_dilakukan dengan penyiraman tanaman_setiap hari. Setelah tanaman menunjukan gejala puru pada akar, tanaman dibongkar. Selanjutnya akar tanaman diekstraksi menggunakan metode modifikasi corong Baermann selama 24 jam dan hasil ekstraksi dimasukkan ke dalam botol. Kemudian hasil ekstraksi diaduk dan diambil sampel $10 \mathrm{~mL}$ dan dituangkan ke dalam cawan petri yang sudah dilapisi dengan plastik hitung_dan selanjutnya populasi nematoda_dihitung di bawah mikroskop.

Varietas tanaman tomat yang digunakan pada penelitian ini adalah varietas Tymoti. Penelitian ini menggunakan 48 tanaman yang terdiri atas 24 tanaman untuk pengamatan 35 hari setelah tanam (hst) dan 24 tanaman untuk pengamatan 77 hst. Media semai tanaman yang digunakan adalah campuran tanah top soil dan pupuk kandang dengan perbandingan $2: 1$ yang telah disterilisasi menggunakan drum pada suhu air $100{ }^{\circ} \mathrm{C}-110{ }^{\circ} \mathrm{C}$ selama dua jam. Media semai steril dimasukan dalam nampan plastik ukuran $30 \mathrm{~cm} \times 40 \mathrm{~cm}$, dengan tinggi $4 \mathrm{~cm}$ dan benih disemaikan di atas media tersebut. Setelah benih tomat berumur dua minggu atau telah mempunyai $4-5$ helai daun, benih siap dipindahtanamkan ke ke dalam polibag yang berisi media steril $10 \mathrm{~kg} /$ polybag.
Setelah dipindah tanamkan dalam polybag, tanaman diinokulasi dengan 1000 ekor larva Meloidogyne spp. instar dua pemupukan dengan pupuk NPK sebanyak $10 \mathrm{~g} /$ tanaman yang diberikan tiga hari sebelum pindah tanam. Pengajiran dilakukan satu minggu setelah tanam dan penyiangan gulma dilakukan setiap minggu.

Pengamatan dilakukan pada umur 35 hst dan 77 hst. Variabel yang diamati dalam penelitian ini adalah tinggi tanaman $(\mathrm{cm})$, bobot basah brangkasan tanaman (g), bobot kering brangkasan tanaman (g), jumlah buah per tanaman, bobot buah per tanaman (g/tanaman), tingkat infeksi nematoda pada akar, tingkat populasi nematoda pada tanah dan tingkat populasi nematoda pada akar

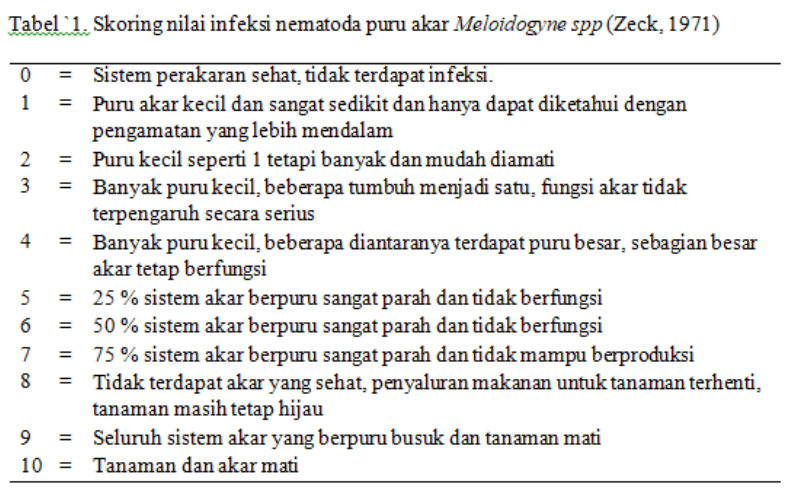

Data yang dikumpulkan dianalisis secara statistik dengan analisis keragaman. Apabila diperoleh hasil yang berbeda nyata maka dilakukan metode Polynomial Orthogonal untuk menentukan model hubungan antara konsentrasi ekstrak daun jarak pagar dan peubah yang diamati.

\section{HASIL DAN PEMBAHASAN}

Perlakuan konsentrasi 10\%, 20\%, 30\%, 40\%, dan 50\% ekstrak daun jarak pagar (Jatropha curcas L.) dalam menghambat serangan nematoda puru akar (Meloidogyne spp.) berpengaruh sangat nyata $(\mathrm{P} \leq 0,01)$ terhadap tinggi tanaman, populasi Meloidogyne spp. pada akar dan tanah tanaman 35 hst dan 77 hst. Selain itu juga berpengaruh nyata (P $\leq 0,05)$ terhadap bobot basah brangkasan tanaman 35 hst, namun berpengaruh tidak nyata $(\mathrm{P}>0,05)$ terhadap bobot basah brangkasan tanaman $77 \mathrm{hst}$ dan bobot kering brangkasan tanaman 35 hst dan 77 hst. Saat tanaman umur 35 hst buah tanaman tomat belum ada yang dipanen, karena buah tomat masih muda dan kecil, sehingga pengamatan jumlah buah dan bobot buah hanya dilakukan saat tanaman berumur 77 hst. Pemberian ekstrak daun jarak pagar berpengaruh sangat nyata $(\mathrm{P} \leq 0,01)$ terhadap jumlah buah dan bobot buah tanaman umur $77 \mathrm{hst}$. 
Konsentrasi ekstrak daun jarak pagar dalam menghambat serangan Meloidogyne spp. membentuk kurva linear terhadap tinggi tanaman tomat umur 35 hst dengan persamaan $\mathrm{y}=32,321+0,2443 \mathrm{x}$ dan $r^{2}=0,9372$. Setiap penambahan $1 \%$ konsentrasi ekstrak daun jarak pagar akan diikuti dengan bertambahnya tinggi tanaman rata-rata 0,2442 $\mathrm{cm}$. Kontribusi konsentrasi ekstrak daun jarak pagar terhadap pertambahan tinggi tanaman rata-rata sebesar $94 \%$

Untuk pengamatan tinggi tanaman tomat 77 hst menunjukkan kurva hubungan kuadratik yang berbeda jika dibandingkan dengan pengamatan hari ke 35 hst. Hubungan antara peubah konsentrasi ekstrak daun jarak pagar dan tinggi tanaman $77 \mathrm{hst}$ dinyatakan dengan persamaan $\mathrm{y}=62,922+0,5152 \mathrm{x}-$ $0,0062 \mathrm{x}^{2}$ dan $\mathrm{r}^{2}=0,8794$. Berdasarkan persamaan tersebut diperoleh konsentrasi optimum ekstrak daun jarak pagar dalam menghambat serangan Meloidogyne spp. sebesar 41,54 \%. Konsentrasi ekstrak daun jarak pagar optimum ini menghasilkan tinggi tanaman maksimum rata-rata sebesar 73,62 $\mathrm{cm}$ (Gambar 1). Perlakuan tanpa ekstrak daun jarak pagar (kontrol) hanya menghasilkan tanaman tomat dengan tinggi $61,49 \mathrm{~cm}$ pada pengamatan $77 \mathrm{hst}$.

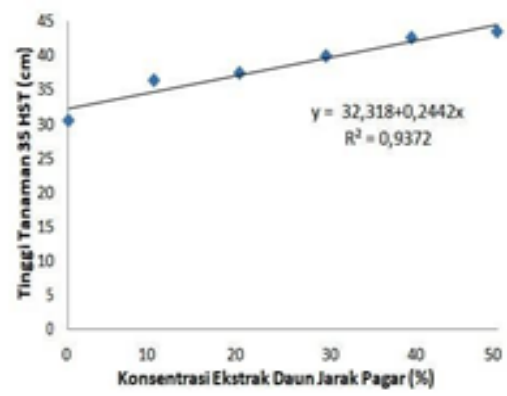

35 hst

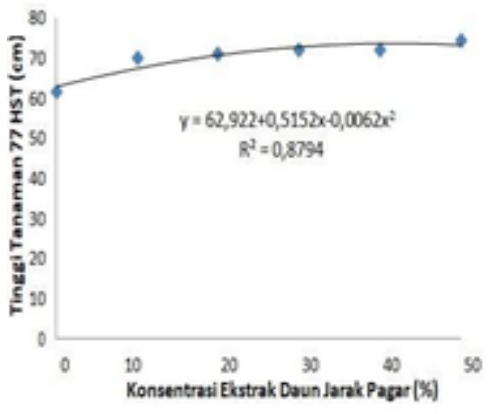

77 hst

Gambar 1. Hubungan konsentrasi ekstrak daun jarak pagar (Jatropha curcas L.) dalam menghambat serangan Meloidogyne spp. terhadap tinggi tanaman tomat $35 \mathrm{hst}$ dan $77 \mathrm{hts}$
Bobot basah dan bobot kering tanaman umur 35 hst terdapat buah tanaman tomat yang masih muda dan kecil sehingga dihitung sebagai bobot brangkasan tanaman. Konsentrasi ekstrak daun jarak pagar berpengaruh nyata terhadap bobot basah brangkasan tanaman 35 hst, namun berpengaruh tidak nyata terhadap bobot basah 77 hst, bobot kering brangkasan tanaman 35 hst dan 77 hst. Hubungan antara konsentrasi ekstrak daun jarak pagar dalam menghambat serangan Meloidogyne spp. terhadap bobot basah brangkasan tanaman 35 hst dinyatakan dengan persamaan linear $\mathrm{Y}=147,65+1,0029 \mathrm{x}$ dengan $\mathrm{R}^{2}=0,8044$. Kontribusi konsentrasi ekstrak daun jarak pagar relatif besar $(80,44 \%)$ terhadap peningkatan bobot basah brangkasan tanaman 35 hst (Gambar 2).

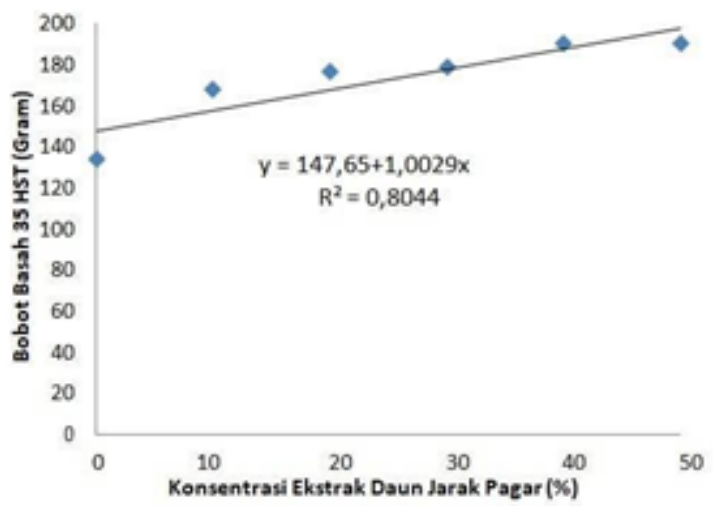

Gambar 2. Hubungan konsentrasi ekstrak daun jarak pagar (Jatropha curcas L.) dalam menghambat serangan Meloidogyne spp. terhadap bobot basah brangkasan tanaman $35 \mathrm{hst}$

Hubungan antara perlakuan konsentrasi ekstrak daun jarak pagar dalam menghambat serangan Meloidogyne spp. terhadap jumlah buah membentuk kurva linear dengan persamaan $\mathrm{Y}=$ $12,786+0,1986 x$ dengan $R^{2}=0,8024$. Sebagaimana pada peubah lainnya, kontribusi konsentrasi ekstrak daun jarak pagar relatif besar terhadap pertambahan jumlah buah $(80,24 \%)$ (Gambar 3).

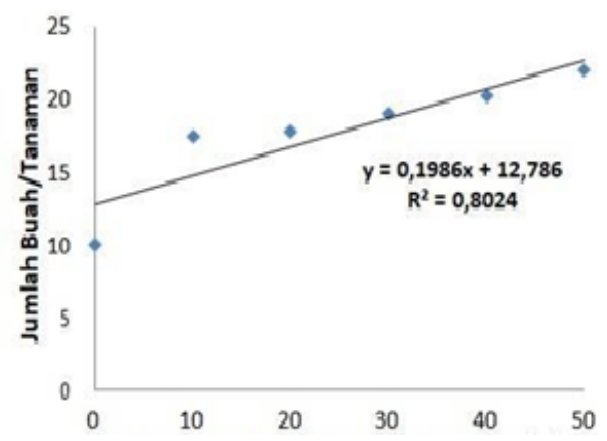

Gambar 3. Hubungan konsentrasi ekstrak daun jarak pagar (Jatropha curcas L.) dalam menghambat serangan Meloidogyne spp. terhadap jumlah buah tanaman tomat 
Perlakuan konsentrasi ekstrak daun jarak pagar dalam menghambat serangan Meloidogyne spp. terhadap bobot buah tanaman tomat membentuk kurva linear dengan persamaan $\mathrm{Y}=$ $251,96+10,671 x$ dengan $R^{2}=0,8949$. Kurva linear konsentrasi ekstrak daun jarak pagar terhadap bobot buah tanaman tomat disajikan pada Gambar 4 .

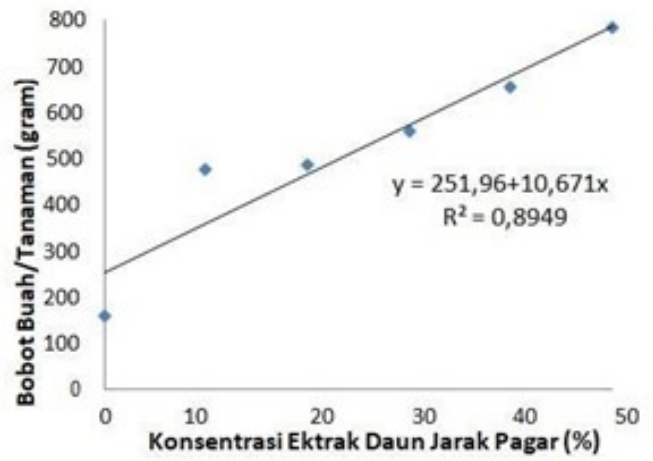

Gambar 4. Hubungan konsentrasi ekstrak daun jarak pagar (Jatropha curcas L.) dalam menghambat serangan Meloidogyne spp. terhadap bobot buah tanaman tomat

Perlakuan konsentrasi ekstrak daun jarak pagar dalam menghambat populasi Meloidogyne spp. pada akar 35 hst membentuk kurva kuadratik dengan persamaan $\mathrm{Y}=24,143-1,1464 \mathrm{x}+0,0164 \mathrm{x}^{2}$ dengan $R^{2}=0,8547$. Konsentrasi optimum ekstrak daun jarak pagar dalam menghambat populasi Meloidogyne spp. terdapat pada konsentrasi 35,95 $\%$ yang menghasilkan 4,11 individu nematoda. Sedangkan perlakuan tanpa ekstrak daun jarak pagar (kontrol) yakni 27,00 individu nematoda. Hal tersebut menunjukkan ekstrak daun jarak pagar mampu menghambat perkembangan populasi Meloidogyne spp. pada akar tanaman tomat $35 \mathrm{hst}$ (Gambar 5).

Perlakuan konsentrasi ekstrak daun jarak pagar dapat menghambat populasi Meloidogyne spp. pada akar tanaman 77 hst melalui kurva linear dengan persamaan $\mathrm{Y}=183,18-4,2471 \mathrm{x}$ dengan $\mathrm{R}^{2}$ $=0,5418$. Hasil ini menunjukkan bahwa setiap peningkatan 1\% konsentrasi ekstrak daun jarak pagar mampu menurunkan populasi nematoda rata -rata sebanyak 4 individu (Gambar 6).

Konsentrasi ekstrak daun jarak pagar dapat menghambat populasi Meloidogyne spp. pada tanah dan tanaman 35 hst dan membentuk kurva linear dengan persamaan $\mathrm{Y}=379,79-5,3164 \mathrm{x}$ dengan $\mathrm{R}^{2}$ $=0,582$. Kurva linear perlakuan konsentrasi ekstrak daun jarak pagar dalam menghambat populasi Meloidogyne spp. pada tanah (Gambar 7).

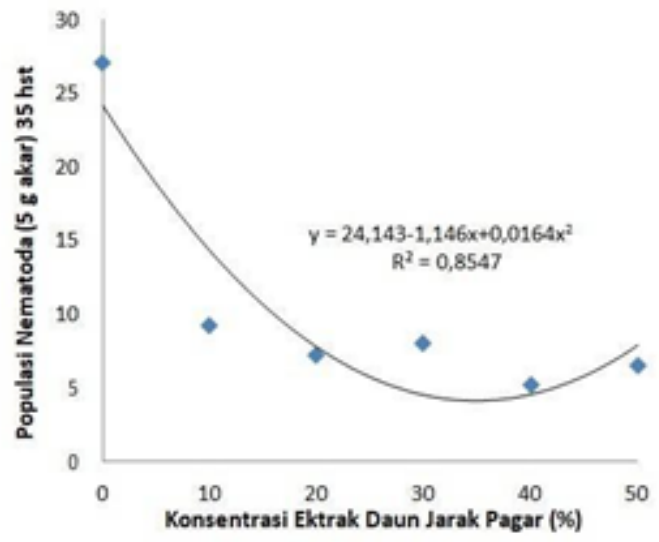

Gambar 5. Hubungan konsentrasi ekstrak daun jarak pagar (Jatropha curcas L.) dalam menghambat populasi Meloidogyne spp. pada akar tanaman tomat 35 hst

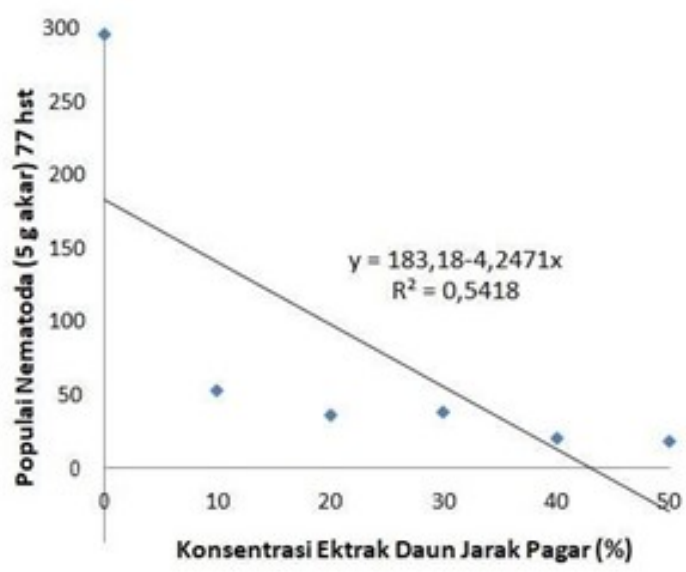

Gambar 6. Hubungan konsentrasi ekstrak daun jarak pagar(Jatropha curcas L.) terhadap populasi Meloidogyne spp. pada akar tanaman tomat $77 \mathrm{hst}$.

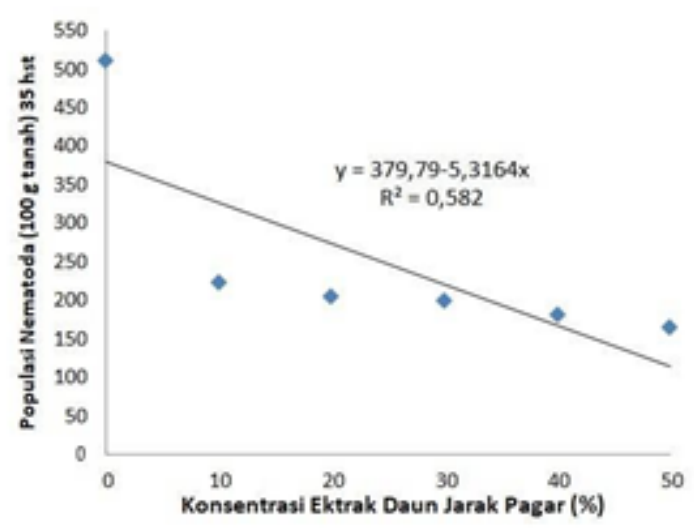

Gambar 7. Hubungan konsentrasi ekstrak daun jarak pagar (Jatropha curcas L.) dalam menghambat, populasi Meloidogyne spp. pada tanah tanaman tomat $35 \mathrm{hst}$ 
Perlakuan konsentrasi ekstrak daun jarak pagar dalam menghambat populasi Meloidogyne spp. pada tanah tanaman tomat $77 \mathrm{hst}$ membentuk kurva linear dengan persamaan $\mathrm{Y}=782,63-12,244 \mathrm{x}$ dengan $\mathrm{R}^{2}=$ 0,8965 . Kontribusi konsentrasi ekstrak daun jarak pagar terhadap populasi Meloidogyne spp. pengamatan umur tanaman tomat 77 hst relatif besar (Gambar 8).

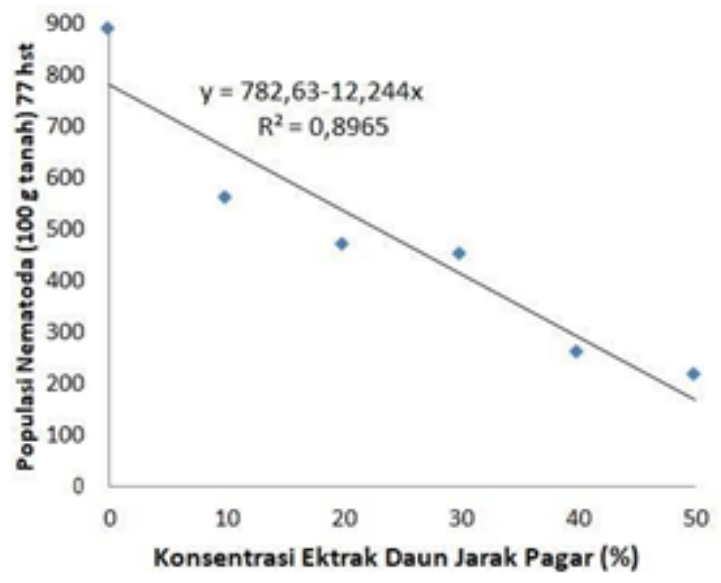

Gambar 8. Hubungan konsentrasi ekstrak daun jarak pagar (Jatropha curcas L.) terhadap Populasi Meloidogyne spp. pada tanah tanaman tomat 77 hst

Tingkat infeksi Meloidogyne spp. pada akar tanaman tomat dilihat dari besarnya kerusakan akar yang disesuaikan dengan kategori serangan berdasarkan skema Zeck. Semakin tinggi nilai dari skema Zeck, maka semakin besar tingkat infeksi Meloidogyne spp. pada tanaman. Kategori kerusakan akar menurut skema Zeck (1971) terdiri atas 11 kategori kerusakan mulai dari 0 yaitu akar lengkap dan sistem akar sehat, tidak terdapat infeksi, hingga kategori 10 yaitu tanaman dan akar mati. Namun dalam penelitian ini kategori kerusakan tertinggi adalah 6 dan terendah ialah 0 .

Konsentrasi ekstrak daun jarak pagar dalam upaya menghambat infeksi Meloidogyne spp. pada akar tanaman umur 35 hst dan 77 hst dengan tingkat infeksi Meloidogyne spp. tertinggi terjadi pada perlakuan tanpa ekstrak daun jarak pagar dengan persentase kerusakan akar $25 \%$ dan $57 \%$. Tingkat infeksi Meloidogyne spp. pada akar tanaman 35 hst perlakuan konsentrasi $40 \%$ efektif dalam menghambat serangan Meloidogyne spp. dengan tingkat infeksi hanya $10 \%$ dibandingkan perlakuan konsentrasi $30 \%$ dan konsentrasi $50 \%$ dengan tingkat infeksi yang sama yaitu $12,5 \%$. Sedangkan tingkat infeksi Meloidogyne spp. pada akar tanaman tomat $77 \mathrm{hst}$ menunjukkan semakin tinggi konsentrasi yang diberikan maka semakin rendah tingkat infeksi Meloidogyne spp. pada akar tanaman tomat.
Secara umum keberadaan Meloidogyne spp. pada tanaman tidak mematikan, namun kepadatan populasi yang tinggi pada tanaman yang masih muda dapat menyebabkan kematian (Semangun, 2001). Pada pengamatan tinggi tanaman, bobot basah tanaman, bobot kering tanaman, jumlah buah, bobot buah, tingkat infeksi Meloidogyne spp. dan kepadatan populasi Meloidogyne spp. menunjukkan bahwa pemberian konsentrasi ekstrak daun jarak pagar mampu menghambat infeksi Meloidogyne spp. dibandingkan tanpa perlakuan ekstrak daun jarak pagar.

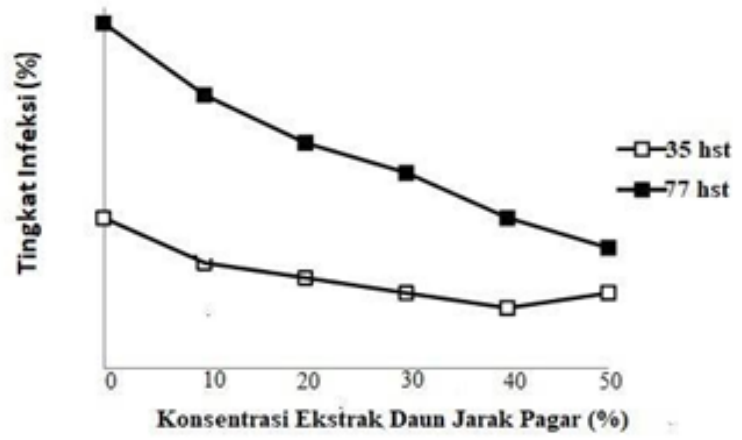

Gambar 9. Tingkat infeksi Meloidogyne spp. pada akar tanaman tomat berdasarkan Skema Zeck (1971)

Tingginya populasi Meloidogyne spp. yang menginfeksi akar menyebabkan terganggunya sistem perakaran dalam menyerap unsur hara dan air. Hasil fotosintesis yang menumpuk pada puru akar digunakan Meloidogyne spp. untuk pertumbuhan dan perkembangbiakannya, sehingga fungsi akar berkurang dalam membantu pertumbuhan tinggi tanaman. Tingkat serangan Meloidogyne spp. yang tinggi akan menyebabkan kerusakan perakaran dan terganggunya penyerapan unsur hara dan air sehingga pertumbuhan tanaman terhambat dan berat tanaman menjadi ringan (Dadan, 1991).. Persentase air yang diserap oleh akar tanaman akan meningkatkan bobot basah tanaman, sedangkan unsur hara yang diserap akar tanaman akan meningkatkan bobot kering tanaman (Sitompul \& Guritno, 1995).

Semakin rendah pemberian konsentrasi ekstrak daun jarak pagar, maka semakin tinggi populasi Meloidogyne spp. pada akar tanaman. Tingginya populasi Meloidogyne spp. pada sistem perakaran menyebabkan pertumbuhan tanaman terhambat yang pada akhirnya mengurangi jumlah bunga dan buah.

Ukuran buah mempengaruhi bobot buah tanaman. Semakin besar ukuran buah tomat, maka semakin berat bobot buah tomat tersebut dan begitu juga sebaliknya. Jumlah buah dan bobot buah menempati posisi terendah pada perlakuan tanpa ekstrak daun jarak pagar karena perakaran tanaman 
terserang Meloidogyne spp. mencapai 57 \%. Sistem perakaran tanaman yang terserang Meloidogyne spp. dapat mempengaruhi proses fotosintesa dan transpirasi sehingga pertumbuhan tanaman terhambat dan produktivitas tanaman menurun (Mustika, 2005). Peningkatan konsentrasi ekstrak daun jarak pagar diikuti dengan membesarnya ukuran buah

Meloidogyne spp. mulai menginfeksi akar tanaman ketika larva memasuki instar kedua. Larva akan bergerak aktif melalui selaput air di antara partikel - partikel tanah dan menyerang akar tanaman dengan melukai epidermis ujung akar dengan stilet, lalu masuk ke dalam jaringan sampai ke jaringan tengah akar dan menghisap cairan sel akar sebagai makanannya. Enzim Pencernaan yang dikeluarkan oleh Meloidogyne spp. dapat merangsang terjadinya pembelahan sel akar sehingga terjadi pembengkakan (Luc et al. 1995). Pada pembentukan puru, nematoda akan mengeluarkan enzim proteolitik dengan melepaskan IAA (Asam indol asetat) yang merupakan hetero auksin triptopan yang membantu terbentuknya puru pada akar tanaman (Lamberti, 1979).

Pemberian ekstrak daun jarak pagar sebagai nematisida nabati pada tanaman tomat memberikan pengaruh positif terhadap tingkat infeksi dan kepadatan populasi Meloidogyne spp., sehingga dapat mempertahankan tinggi tanaman, bobot tanaman, jumlah buah, dan bobot buah. Hal ini disebabkan adanya kandungan senyawa aktif dari ekstrak daun jarak pagar yang seperti tanin, alkaloid, flavonoid,saponin dan fenol yang dapat menghambat perkembangan Meloidogyne spp (Nwokocha et al.,.2011). Senyawa alkaloid dan flavonoid menjadi kombinasi yang baik dalam menghambat penetasan telur Meloidogyne spp. melalui pengaruh berupa terganggunya perkembangan embrio sehingga telur tidak menetas (Adegbite \& Adesiyan, 2005). Selain alkaloid dan flavonoid diduga ada senyawa tanin dan saponin juga mempengaruhi perkembangan telur nematoda (Huzni et al., 2015). Selain itu senyawa tanin dilaporkan dapat bereaksi dengan protein penyusun sel-sel serta menyebabkan denaturasi pada protein sehingga dapat mengurangi kemampuan nematoda dalam menginfeksi akar (Lopez, 2005). Efek tanin terhadap dinding sel kulit larva adalah dapat memblokade respon otot nematoda terhadap asetilkolin sehingga nematoda menjadi lumpuh dan mati (Nezriyetti \& Novita, 2012).

Hasil pengamatan tingkat infeksi dan kepadatan populasi Meloidogyne spp. pada akar dan tanah menunjukkan terjadinya peningkatan infeksi dan populasi Meloidogyne spp. dari tanaman $35 \mathrm{hst}$ hingga 77 hst yang diperlakukan dengan ekstrak daun jarak pagar, meskipun lebih rendah dibandingkan perlakuan tanpa ekstrak daun jarak pagar (kontrol). Hal ini diduga karena Meloidogyne spp. yang masih hidup setelah diberi perlakuan, mampu melahirkan keturunan sehingga populasi Meloidogyne spp. menigkat. Selama hidupnya, nematoda betina akan terus-menerus menghasilkan telur hingga mencapai 1000 telur (Luc et al., 1995). Selain itu diduga ekstrak daun jarak pagar yang digunakan sebagai nematisida nabati terurai/ tercuci karena curah hujan dan sinar matahari. Senyawa-senyawa alami dari tumbuh-tumbuhan memiliki sifat mudah terurai di alam bebas terutama karena faktor cuaca (Prakash \& Rao, 1997). Pemberian ekstrak daun jarak pagar sebagai nematisida nabati perlu dilakukan berulang atau lebih dari sekali untuk keefektifan ekstrak daun jarak pagar dalam menghambat serangan Meloidogyne spp. pada tanaman tomat.

\section{KESIMPULAN}

Ekstrak daun jarak pagar (Jatropha curcas L.) dapat digunakan dalam menghambat serangan nematoda puru akar (Meloidogyne spp.) pada tanaman tomat

Meskipun semakin besar pemberian konsentrasi ekstrak daun jarak pagar akan memperkecil tingkat infeksi dan populasi Meloidogyne spp., konsentrasi ekstrak daun jarak pagar sebesar 35\% - $45 \%$ merupakan konsentrasi yang optimum dalam menghambat serangan Meloidogyne spp.

\section{DAFTAR PUSTAKA}

Adegbite, A. A., \& Adesiyan, S. O. (2005). Root extracts of plants to control root-knot nematode on edible soybean. World Journal of Agricultural Sciences, 1(1), 18-21.

Adiputra, M. G. (2006). Pengantar Nematologi Tumbuhan. Jurusan Hama dan Penyakit Tumbuhan Fakultas Pertanian Universitas Udayana, Denpasar.

Badan Pusat Statistik. (2015). Statistik Produksi Tanaman Sayuran dan Buah-buahan. BPS, Jakarta.

Dadan, S. (1991). Evaluasi Pengaruh Getah Pepaya Terhadap Meloidogyne spp. Penyebab Puru Akar Pada Tomat Lycopersicum esculentum Mill. Jurusan Hama dan Penyakit Tumbuhan Fakultas Pertanian. Institut Pertanian Bogor, Bogor.

Dropkin, V.H. (1992). Introduction to Plant Nematology. Second Edition. Departemen of Plant Phathology. University of Missouri. Columbia. Diterjemahkan oleh Supratoyo. 1996. Pengantar Nematologi Tumbuhan. Edisi Kedua. UGM Press. Yogyakarta. 
Huzni, M., Rahardjo, B. T., \& Tarno, H. (2015). Uji Laboratorium Ekstrak Kirinyuh (Chromolaenaodorata: King \& Robinson) Sebagai Nematisida Nabati terhadap Meloidogyne spp. (Chitwood). Jurnal Hama dan Penyakit Tumbuhan, 3(1), 93-101.

Isenring, R. (2010). Pesticides and the loss of biodiversity. Pesticide Action Network Europe, London, 26.

Javed, N., Gowen, S. R., Inam-ul-Haq, M., Abdullah, K., \& Shahina, F. (2007). Systemic and persistent effect of neem (Azadirachta indica) formulations against root-knot nematodes, Meloidogyne javanica and their storage life. Crop Protection, 26(7), 911-916.

Lamberti, F. \& Taylor, C.E. (1979). Root Knot Nematodes Biology And Control. Academic Press., London. pp 173-374.

Las, I., Subagyono, K. \& Setiyanto, A. P. (2006). Isu dan pengelolaan lingkungan dalam revitalisasi pertanian. Jurnal Litbang Pertanian, 25 (3), 106-114.

Lopez, J., Ibarra, O. F., Canto, G. J., Vasquez, C. G., Tejada, Z. I., \& Shimada, A. (2005). In vitro effect of condensed tannins from tropical fodder crops against eggs and larvae of the nematode Haemonchus contortus. Int. J. Food, Agric. \& Environ, 3(2), 191-194.

Luc, M., Sikora, R.A. \& Bridge, J. (1995). Nematoda Parasitik Tumbuhan di Indonesia Subtropik dan tTropik. Diterjemahkan oleh Supartoyo dan Mulyadi, Gadjah Mada University Press., Yogyakarta.

Mustika, I. (2005). Konsepsi dan strategi pengendalian nematoda parasit tanaman perkebunan di Indonesia. Jurnal Perspektif, 4(1), 20-32.

Nagaraju, N., Venkatesh, M.H., Warburton, H., Muniyappa, V., Chancellor, T.C.B. \& Colvin, J. (2002). Farmers perceptions and practices for managing tomato leaf Curl Virus Disease in Southern India. International Journal Pest Management, 48, 333-338

Natawigena, (1985). Pestisida dan Kegunaannya. Cetakan ke dua. dalam Santosa, B. (2018). Penyaringan galur kedelai terhadap penyakit karat daun isolat Arjasari di rumah kaca. Balai Penelitian Bioteknologi dan Sumber Daya Genetik, Bogor.
Nezriyetti \& Novita, T. (2012). Effectiveness of Jatropha curcas leaf extract to inhibits the development of Meloidogyne spp. nematode on tomato roots. Biospecies, 5(2), 35-39.

Nwokocha, A., Blessing, I. O., Agbagwa, I. O., \& Okoli, B. E. (2011). Comparative phytochemical screening of Jatropha L. species in the Niger Delta. Research Journal of Phytochemistry, 5(2), 107-114.

Orden, M. E. M., Patricio, M. G., \& Canoy, V. V. (1994). Extent of pesticide use in vegetable production in Nueva Ecija: Empirical evidence and policy implications. Research and development highlights, 94, 196-213.

Prakash \& Rao. (1997). Botanical Pesticides in Agriculture. CRC Press. Inc Florida. Price,

Price, T.V. (2001). Practical Manual Detection and Identification of Nematodes. Department of Agriculture.

Semangun, H. (2001). Ilmu Penyakit Tumbuhan. Cet ke-2. Gadjah Mada University Press., Yogyakarta.

Sharma, A. K., Gangwar, M., Tilak, R., Nath, G., Sinha, A. S. K., Tripathi, Y. B., \& Kumar, D. (2012). Comparative in vitro antimicrobial and phytochemical evaluation of methanolic extract of root, stem and leaf of Jatropha curcas Linn. Pharmacognosy Journal, 4(30), 34-40.

Sitompul, S.M. \& Guritno, B. (1995). Analisis Pertumbuhan Tanaman. Fakultas Pertanian. Gajah Mada University Press., Yogyakarta.

Taylor, A.L. \& Sasser, J.N. (1978). Biologi, identification and control of root knot nematodes (Meloidogyne spp) International Carolina Meloidogyne Project. Printed by Nor Carolina State University Graphics. 107 page.

Tohir, A. M. (2010). Teknik ekstraksi dan aplikasi beberapa pestisida nabati untuk menurunkan palatabilitas ulat grayak (Spodoptera litura Fabr.) di laboratorium. Buletin Teknik Pertanian, 15(1), 3740.

Whitehead, A.G. (1998). Plant Nematode Control. CAB International, Wallingfortd, UK.

Zeck, W. M. (1971). Rating scheme for field evaluation of root-knot nematode infestations. Pflanzenschutz nachrichten Bayer, 24, $141-144$. 